\title{
An empirical study of auditors switching, corporate governance and financial performances of Malaysian Public Listed Companies (PLCs)
}

\begin{abstract}
In the past years, regulators and the business communities had expressed worries about the alarming rate at which firms or corporations collapse due to the mismanagement and manipulation of resources as seen in the cases of Enron, WorldCom in the United States of America; and to be specific in Malaysia, the cases of Megan Media Holdings Berhad and Transmile Group. Auditor switching is evident and the disorder of auditor switching often takes place in Malaysia; however, as time goes by, it is decreasing. Thus, this paper seeks to empirically examine the effect of auditor switching and corporate governance on financial performance of Malaysian PLCs. Secondary data on a total number of 100 PLCs from years 2009 to 2013 are used. The results reveal that the effect of auditor switching on performance does not vary with duality role and the board size. However, the independent director does not cause a good firm performance. Nonetheless, auditors do not have a direct effect on financial performance since they are not directly involved with the management of the firms which negates the results of previous study. Therefore, this paper has vital impact in that regulators and the public need to be educated through awareness campaigns to emphasize on the auditors' roles as agents in understanding the impact of the association between corporate governance and financial performance. Furthermore, auditor switching should embrace not only rotation of audit partners, but rotation of audit firms as well in view that this will help in infusing discipline from the top to the bottom of the audit firms and the companies.
\end{abstract}

Keyword: Corporate governance; CEO/chairman duality; Board size; Independent directors; Auditor switching; Financial performance; Return on Assets (ROA); Return on Equity (ROE); Tobin's Q; Malaysia 